A Péterfy Kórház-Rendelóintézet Országos Traumatológiai Intézet ${ }^{1}$, a Pécsi Tudományegyetem, Gyermekklinika, Sebészeti Osztály² és a Szegedi Tudományegyetem, Traumatológiai Klinika és Tanszék ${ }^{3}$ közleménye

\title{
Gyermekkori nagy diszlokációval járó distalis radius metaphysis törések kezelése rövid elasztikus velöúrszegezési technikával
}

\author{
DR. VARGA MARCELL1', DR. KASSAI TAMÁS ${ }^{1}$, DR. BÍRÓ ZSUZSA ${ }^{1}$ \\ DR. KALÓZ ERIKA ${ }^{1}$, DR. GÁTI NIKOLETT ${ }^{1}$, DR. PINTÉR SÁNDOR ${ }^{3}$
}

\section{ÖSSZEFOGLALÁS}

A radius distalis végének törése az egyik leggyakrabban előforduló sérülésforma gyermekkorban. A nagy diszlokációval, teljes periosteum átszakadással és összecsúszással járó törések mútéti indikációt képeznek. A mútéti megoldást többnyire tűződrótos osteosyinthesis és kiegészítő 4-6 hetes gipszrögzítés jelenti. Az alkartöréseknél sikeresen alkalmazott ESIN technika (Elastic Stable Intramedullary Nailing) módosított módszereivel a növekedési porcot elkerülö, minimál invazív technikával olyan stabil szintézis érhető el, amely a posztoperatív rögzítési időt is jelentősen redukálja. Cikkünkben a rövid kettős, illetve lágyrészvédelemmel ellátott rövid monoelasztikus velőűrszegezést, ezek technikáját, illetve retrospektíven feldolgozott eredményeinket ismertetjük. 2013. október és 2017. október között két centrumban összesen 84 gyermek rövid kettős elasztikus szegezését végeztük el, míg 16 gyermeknél lágyrészvédővel ellátott monoelasztikus szegezés történt. A mútéti indikáció valamennyi gyermeknél zárt, az alkar distalis harmadára lokalizálódó, nagy diszlokációval, és mindkét corticalis átszakadásával járó metaphysis vagy dia-metaphysealis átmenetben elhelyezkedő törés volt. A physisek valamennyi esetben nyitva voltak, a gyermekek életkora 4-14 év között volt. Implantátum vándorlás nem alakult ki. Mély szeptikus szövődményt egy esetben sem észleltünk. Három esetben felületes infekció alakult ki a kettős szegezéssel ellátott csoportban, a szegek eltávolítását követően a panaszok megszűntek, a törés az eltávolítás idején már konszolidált. A kettős elasztikus szeggel ellátott csoportban öszszesen további 9 gyermeknél észleltünk az implantátumvég által okozott bőrirritációt. A fémek eltávolítása után ezek a panaszok maradéktalanul megszűntek. A lágyrészvédelemmel ellátott csoportban implantátum okozta irritációt nem észleltünk. Ín-, illetve idegsérülést egyik csoportban sem találtunk. Az utánkövetési idő 9 hónap - 4 év volt, valamennyi gyermek teljes, oldalazonos funkcióval gyógyult. A féléves kontroll során készült röntgenfelvételen, a remodellációs szak lezajlását követően, egy kivétellel a radiuson, valamennyi esetben anatómiai tengelyállást észleltük. A rövid szegezési technika jó alternatívája lehet a tűződrótos osteosynthesisnek. Előnye a physisek elkerülése, a mozgásstabil szintézis, a csökkent idejű és egyszerűsített külső rögzítés, és a gyermekek gyors rehabilitációja. A sikeres mútéti technika az ESIN technikában, illetve gyermektraumatológiában való jártasságot igényel.

\section{Kulcsszavak: $\quad$ Gyermekkor; Intramedullaris töréskezelés; Radius törés; Szegezés;}

M. Varga, T. Kassai, Zs. Bíró, E. Kalóz, N. Gáti, S. Pintér: Treatment of completely displaced distal metaphyseal fractures of the radius in children with short elastic nailing

Fractures of the distal radius are the most common injuries in children. Completely displaced and shortened fractures with periosteal rupture are candidates for osteosynthesis. The most common operative treatment is percutaneous pinning with rigid long cast immobilization for 4-6 weeks postoperatively. Using a modified ESIN method (Elastic Stable Intramedullary Nailing) a very stable, physis sparing, minimally invasive osteosynthesis can be achieved, without the need of long cast immobilization. In our paper we present the operative technique of short double elastic and soft tissue protected monoelastic nailing, and retrospectively analyze the results of our 
interventions. We reviewed retrospectively patients who underwent short double elastic or softtissue-protected nailing due to distal radial metaphyseal fractures between October 2013 and October 2017 in two Pediatric Trauma Centres. Indications for surgery included closed, severely displaced unstable metaphyseal or meta-diaphyseal radial fractures of the radius. We treated 84 children with double elastic and 16 children with mono-elastic short nails. Age of the patients was between 4 and 14 years, and all of them had open growth plates. The average follow-up time was 18.8 months (9-48 months). We have not seen any migration of the implants. There was no deep infection either. At three children a superficial skin infection has been observed, which was eliminated by removing the nails. 9 children complained to a mild skin irritation which also resolved by implant removal. Patients with soft tissue protected mono-elastic nail have not had this complain. There was no tendon or nerve injury. All of the patients regained full range of motion without further complications. Radiological remodellation was perfect in all except one case after six months. Short elastic nailing may be a good alternative technique of percutaneous pinning. Its advantage is the physis sparing method, which is stable, and reduces the time of rehabilitation. Further prospective and biomechanical investigations are necessary to verify our experience.

Keywords: $\quad$ Bone nails; Child; Fracture fixation, intramedullary-Methods; Radius fractures - Surgery;

\section{BEVEZETÉS}

A radius distalis végének törése az egyik leggyakrabban előforduló sérülésforma gyermekkorban (11). Konzervatív kezeléssel az esetek 80-90 százalékában (torus törések, epiphyseolysisek, periosteum folytonosságát megtartó, diszlokáció nélküli és angulációval járó metaphysis törések) kiváló eredmények érhetőek el (2).

A nagy diszlokációval, teljes periosteum átszakadással és összecsúszással járó törések ugyanakkor még gyermekkorban is mútéti indikációt képezhetnek $(2,16)$. Mútéti ellátás indokolt, ha a törés primeren reponálhatatlan, illetve korai rediszlokáció alakul ki, amely a várható remodellációs kapacitást meghaladja $(2,16,19)$.

Gyermekkorban a distalis radius törések mútéti stabilizálásának legáltalánosabban elfogadott módszere a fedett, túződrótos osteosynthesis és kiegészítő gipszrögzítés (8, 17, 19). A felnőttkorban használatos lemezes szintézis a physisek hiperstimulálása, a következményes növekedési zavar lehetősége és nyílt mútét miatt 14 éves kor alatt nem ajánlott.

A tűződrótos osteosynthesisnek ugyanakkor számos hátránya is ismert. A drótok elvándorolhatnak, a bevezetés helyén sokszor bőrirritáció illetve felületes infekció alakulhat ki, a törésben rediszlokáció léphet fel, illetve a szintézis csak mozgás stabil, így 4-6 hetes, a könyökízületet is immobilizáló gipszrögzítést is igényel gyakori kontrollvizsgálatokkal $(7,20$, 21).

Külön problémát jelentenek a diametaphysis határon elhelyezkedő törések, amelyeknél a túződrótok nem pozícionálhatóak úgy, hogy a proximalis darabot is megfelelően rögzítsék. Ezeknél a töréseknél egyes szerzők a növekedési porcon átvezetett szintézist ajánlják, bár ismeretes, hogy ezzel a későbbi növekedési zavarok kockázatát növelik $(14,15)$.

$\mathrm{Az}$ Országos Traumatológiai Intézet Gyermektraumatológiai Osztályán az elmúlt években több olyan eljárás is bevezetésre került, melyekkel a fenti problémák kiküszöbölhetőek. Az alkartöréseknél sikeresen alkalmazott ESIN technika módosított módszereivel a növekedési porcot elkerülő, minimál invazív technikával, olyan stabil szintézis érhető el, amely a posztoperatív rögzítési időt is jelentősen redukálja. Cikkünkben kizárólag a rövid kettős, illetve lágyrészvédelemmel ellátott monoelasztikus velőűrszegezést, ezek technikáját illetve retrospektíven feldolgozott eredményeinket ismertetjük. 


\section{MÜTÉTI TECHNIKA}

\section{Kettös rövid elasztikus szegezés}

A mútét általános narkózisban történik. $A$ gyermek a hátán fekszik, karja nyújtott helyzetben karasztalon. A mútét egyes lépései képerősítő kontroll mellett történnek, amelyet célszerű a beteg láb felőli oldaláról vezetni, míg az operatőr a fej felőli oldalon ül. Vértelenítő mandzsetta alkalmazása a mútéthez nem feltétlen követelmény, de ajánlott, amennyiben a szegek bevezetési pontjait - az ín védelme céljából - kis feltárásból kívánjuk végezni. Lemosást és izolálást követően először a radius distalis végének repozícióját végezzük el. Amennyiben ez fedett manuális manőverekkel nem kivitelezhető, célszerű egy, a törési résbe dorsalis irányból bevezetett vastag tǔződróttal (2.5-3 mm) segíteni a helyretételt. A drót tompa végét a törési résbe vezetve, emelő mechanizmussal, a distalis darab még jelentős összecsúszás esetén is ráemelhető a radius proximalis végére (1. ábra).

A repozíciót követőn kiválasztjuk a szegeket. Relatív vastag, 2.5-3-as szegeket célszerű választani, amelyeket egy körülbelül 10-12 cm hosszúságú szakaszon „C" alakúvá hajlítunk. A szeg első bevezetési pontja, dorsalisan, a Lister tuberculum radialis oldala. A velőurr megnyitását a physistől proximalisan, azt nem érintve, de ahhoz a legközelebb kell megcélozni, hogy a kis distalis darabban a szeg jó tartást biztosítson a későbbiekben. Ezt követően bevezetjük az előre meghajlított szeget úgy, hogy a legnagyobb görbülete palmaris irányba tekint. A szeget óvatosan, görbülete mentén vezetjük előre, amíg a vége bele nem akad a proximalis törtdarab velóüregébe. Ekkor a szeg megfeszül, és további kontrollált erőbehatással, még néhány $\mathrm{cm}$-es szakaszon továbbvezethető a velőüregben. Optimális esetben a szeg legnagyobb görbülete a törési rés magasságában van. Fontos, hogy a szeget sem ütni, sem feszegetni nem szabad, mert ezzel további iatrogén törést okozhatunk. Ha a görbület túl nagy, és a szeg nem vezethető át a proximalis törtdarabba, vagy $1-2 \mathrm{~cm}$ után elakad és a nagy feszülés miatt nem vezethető tovább, célszerű visszahúzni, és korrigálni az ívén, vagy vékonyabb szeget választani.
Az első szeg bevezetését követően kerülhet sor a radialis irányból való második szeg behelyezésére. A bevezetési pont itt a radius distalis és radialis oldala a physistől proximalisan, a konvencionális ESIN technikánál megszokott módon. A második szeg a rotációt stabilizálja, így lehet vékonyabb az előzőnél, kevésbé kifejezett előrehajlítással. A radialis corticalis megnyitása után ezt a szeget is gördítve helyezzük be, a szeg konvexitása a radius ulnaris oldala felé néz. A törési résen való sikeres átjutás után ezt a szeget is néhány $\mathrm{cm}$ mélységben vezetjük még tovább, amíg a feszülés engedi. A két szeg proximalis vége általában $1-2 \mathrm{~cm}$ szintkülönbségben helyezkedik el. Amennyiben a tengelyállás nem megfelelö, a szegek óvatos pozícionálásával ilyenkor még korrigálni tudjuk. A repozíció során a kis ad latus diszlokációk nem jelentenek problémát, alapvetően a radius distalis végének remodellációs kapacitását nem meghaladó tengelyállásra kell törekedni. A gyermek korától függőn 10-15 fokos dorsovolaris, illetve $5 \mathrm{~mm}$-es ad latus tengelyeltérés is elfogadható, egyes esetekben a régió jó remodellációs potenciálja miatt, de alapvetően anatómiai repozícióra célszerű törekedni.

A radius stabilizálása után, az ulna törésének jelenléte esetén annak a velőúrszegezését is javasoljuk elvégezni a kellő stabilitás megteremtéséhez. Az ulna velőűrszegezése proximalis irányból történik és semmiben sem tér el a klasszikus ESIN technikánál alkalmazott elvektől.

Szeglevágás: A szegek végét hajlított kéztartás mellett, a bőr szintje alatt vágjuk le. A szegek szabad distalis végének pozícionálása különösen kritikus, mivel a túl hosszúra hagyott implantátumok bőrirritációt, míg a túl rövid, a corticalis szintjét éppen csak meghaladó fémvégek kivételi nehézséget, ínsérülést okozhatnak.

A mútétet követőn a végtagot néhány napig palmaris gipszsínben, majd rövid tépőzáras brace-ben rögzítjük. A külső rögzítés általában 1-2 hét, de legkésőbb 4 hét után teljesen elhagyható.

Fémkivétel a teljes radiológiai konszolidációt követően javasolt narkózisban vagy helyi érzéstelenítésben, leghamarabb 6-8 hét után, általában 3-4 hónapos korban (2-3. ábrák). 


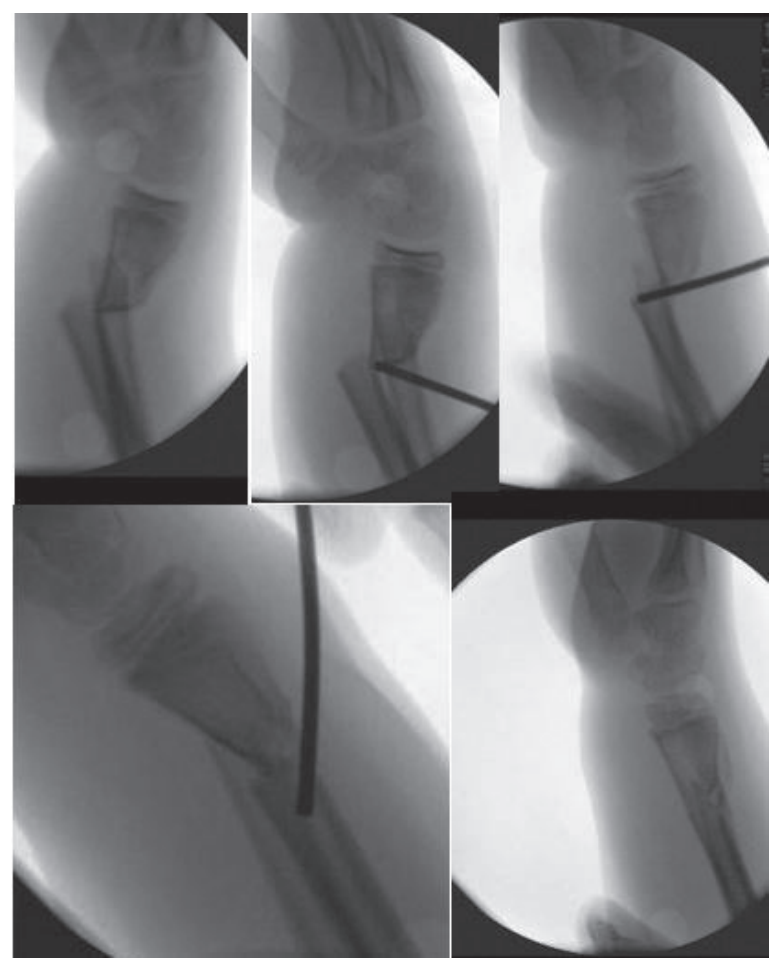

1. ábra

Repozíció tompa végü tüződróttal. A törési résbe dorsalis irányból vezetett tompa végü eszközzel a distalis darab ráemelhetö a proximalis törtdarabra

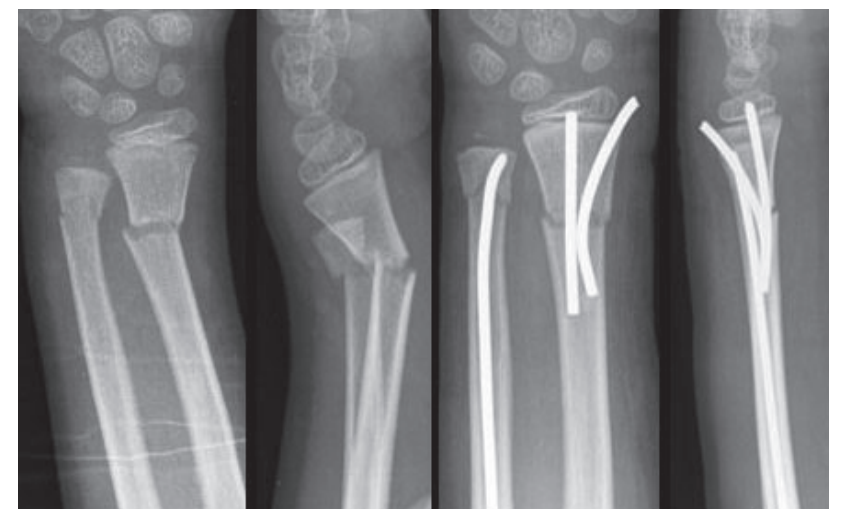

2. ábra
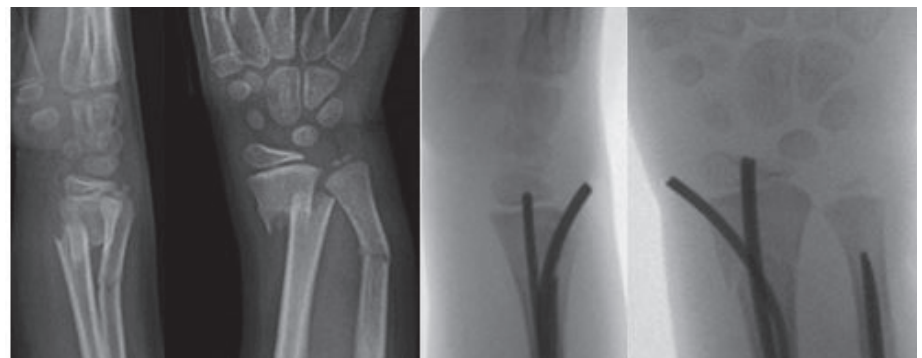

3. ábra

\section{2-3. ábra}

Dia-metaphysealis hátáron elhelyezkedö, illetve distalis metaphysis régióban kialakult radius törések kezelése kettős szegezéssel. Az ulna egyidejü törése miatt mindkét esetben annak szegezése is megtörtént, a szintézis így mozgásstabillá válik 


\section{Módosított, lágyrészvédővel ellátott rövid szegezés egy implantátummal}

A mútéti technika kezdeti lépései megegyeznek a kettős szegezésnél leírtakkal. Fontos különbség, hogy a mútét itt mindig vértelenítő mandzsetta használata mellett történik, hogy a lágyrész védő behelyezése során az inakat ne sértsük.

A repozíciót követően a physistől proximalisan, dorsalisan a középvonalban másfél $\mathrm{cm}$-es haránt metszést ejtünk. Az extensor inakat látótérbe hozzuk, a velőúr megnyitása az inak között, a radius középvonalában történik. A distalis darabba a korábbiakban leírt módon vezetjük be az előrehajlított szeget, úgy hogy a konvexitás palmaris irányba tekint. A repozíciót és a szeg pozícionálását követően a szeg végét úgy vágjuk le, hogy nagyjából $1 \mathrm{~cm}$-es szakasz maradjon szabadon. Az inak széthúzása és egyértelmű láthatóvá tétele után lágyrészvédő, menetes végű Endcapot ${ }^{\circledast}$ csavarunk a szeg végére. Az Endcap ${ }^{\circledR}$ nem haladhat át a physisen, és nem is érintheti azt.

Egyidejú ulnatörés esetén itt is elvégezzük az ulna konvencionális, proximalis irányból vezetett anterográd velőúrszegezését.

A mútét végén a bőrt az Endcap ${ }^{\circledR}$ felett zárjuk. Ha az Endcap ${ }^{\circledR}$ a bőrt nagyon előboltosítja, vagy feszülést okoz, akkor azt célszerú inkább eltávolítani és a szeget rövidebbre vágni, vagy mélyebbre helyezése után ismét rácsavarni (4-5. ábrák). Az utókezelés hasonló a fentiekben leírtakhoz.

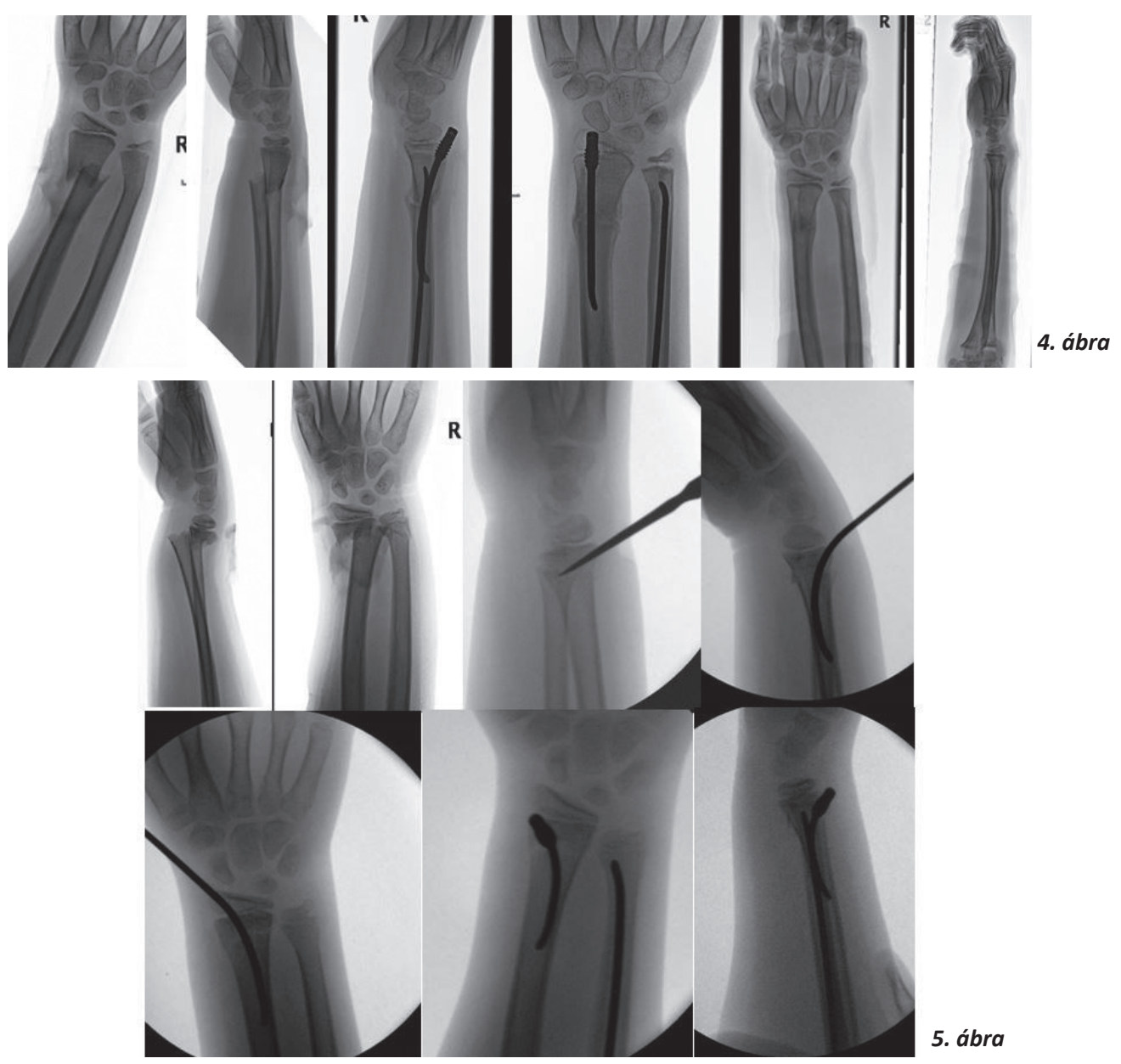

4-5. ábra

Lágyrészvédővel (Endcap ${ }^{\circledR}$ ) ellátott szegezés. A lágyrészvédő a physist nem érinti. A szeg bevezetési pontjának gondos meghatározásával még az egészen kis metaphysis darabbal rendelkező törések is stabilizálhatóak 


\section{ANYAG ÉS MÓDSZER}

2013. október és 2017. október között, két centrumban, összesen 84 gyermek rövid kettős elasztikus szegezését végeztük el, míg 16 esetben lágyrészvédővel ellátott monoelasztikus szegezés történt. Valamennyi mútét Synthes TEN $^{\circledR}$, illetve Endcap ${ }^{\circledR}$ implantátumokkal történt. A mútéti indikáció valamennyi gyermeknél zárt, az alkar distalis harmadára lokalizálódó, nagy diszlokációval, és mindkét corticalis átszakadásával járó metaphysis vagy dia-metaphysealis átmenetben elhelyezkedő törés volt. A physisek valamennyi esetben nyitva voltak, a gyermekek életkora 4-14 év között volt. A törések közül valamennyi zárt volt. A mútéteket összesen hat, gyermektraumatológiai ellátásban tapasztalt gyermeksebész, vagy traumatológus szakorvos, illetve szakorvosi asszisztencia mellett szakorvos jelölt végezte.

\section{EREDMÉNYEK}

Sem a kettős szegezéssel, sem a lágyrészvédelemmel ellátott mono-elasztikus szeggel ellátott csoportban nem került sor reoperációra. Implantátum vándorlás nem alakult ki. Mély szeptikus szövődményt egy esetben sem észleltünk.

Három esetben felületes infekció alakult ki a kettős, egy esetben a monoelasztikus szeggel ellátott csoportban, a szegek eltávolítását követően a panaszok megszúntek, a törés az eltávolítás idején már konszolidált.

A kettős elasztikus szeggel ellátott csoportban, összesen további 9 gyermeknél észleltünk az implantátum vég által okozott bőrirritációt. A fémek eltávolítása után ezek a panaszok maradéktalanul megszűntek. A lágyrészvédelemmel ellátott csoportban implantátum okozta irritációt nem észleltünk. Ín-, illetve idegsérülést egyik csoportban sem találtunk. Az implantátumokat a 6-24. hét között - egy kivételével - minden gyermekből eltávolítottuk. Egy esetben a túl mélyre került implantátumot nem tudtuk kivenni.

Az utánkövetési idő 9 hónaptól 4 évig terjedt, valamennyi gyermek teljes, oldalazonos funkcióval gyógyult. Mozgásbeszúkülés, kései növekedési zavar egy gyermeknél sem alakult ki (6. ábra, l. táblázat).

A mútét után közvetlenül, a negyedik héten, illetve fél éves korban, fémeltávolítás után készült röntgenfelvételeket elemezve az alábbi eredményekre jutottunk:

A posztoperatív szakban (0-1. hét) végzett röntgenképeket anatómiainak tekintettük, ha mind $\mathrm{AP}$, mind oldalirányból a maximális tengelyeltérés 5 fok alatti, jónak, ha 15 fok alatti volt, elfogadhatónak 30 fokig, ha az életkort is figyelembe véve a remodellációs határ alatti volt, illetve rossznak, ha a tengelyeltérés értéke nagyobb volt, mint a várható remodellációs potenciál.

A kettős szegezéssel ellátott csoportban 70 gyermeknél anatómiai, 13 gyermeknél jó, 1 gyermeknél elfogadható helyzetet állapítottunk meg. Az Endcap ${ }^{\circledR}$-val ellátott csoportban, 13 esetben anatómiai, 3 esetben jó eredményt találtunk. A kettős szegezéssel ellátott csoportban, a négyhetes korban végzett kontrollröntgen némileg rosszabb radiológiai eredményt mutatott: 4 gyermek besorolása az anatómiai helyzetről jóra, 3 gyermek helyzete a jó besorolásról elfogadhatóra változott, míg egy gyermeknél rossz kategóriát állapítottunk meg. A féléves kontroll során készült felvételen ugyanakkor, a remodellációs szak lezajlását követően, egy kivétellel, valamennyi esetben anatómiai tengelyállást észleltünk. Ez utóbbi betegnél is, az egyéves radiológiai kontrollvizsgálat már jó helyzetet mutatott.

A lágyrészvédővel ellátott csoportban nem észleltünk változást a néhány hetes posztoperatív és féléves radiológiai felvételek elemzése során (II. táblázat). 


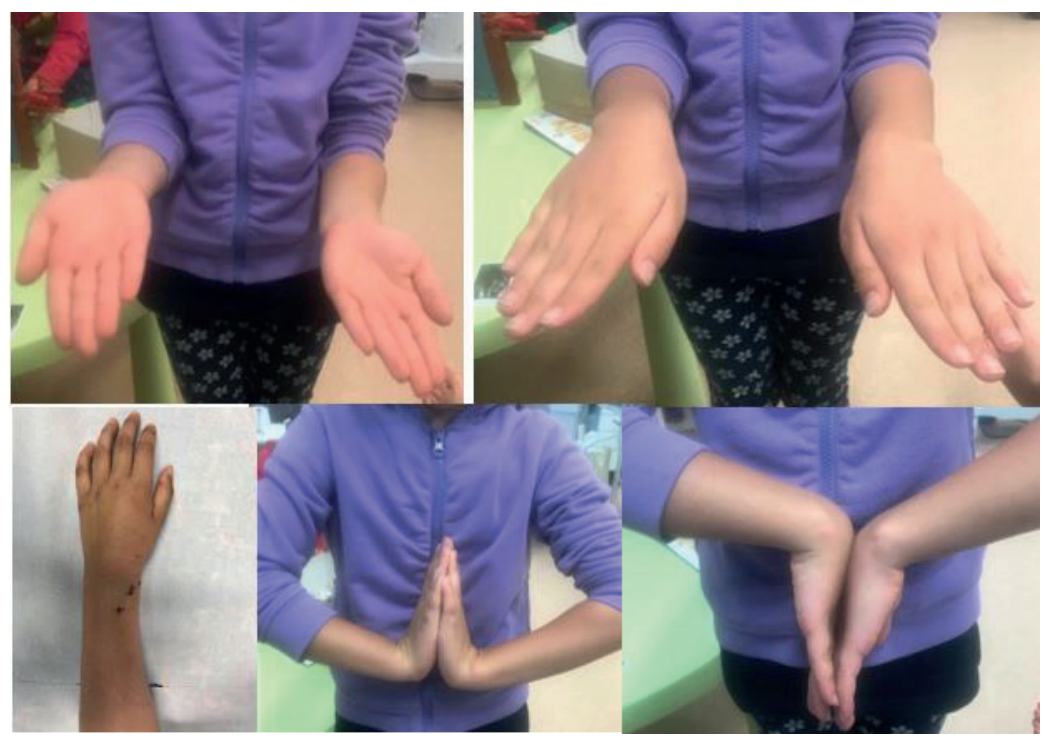

6. ábra

Friss mütéti hegek, illetve 1 éves posztoperativ funkció

\begin{tabular}{|c|c|c|c|}
\hline Kettős elasztikus szegezés & $\mathrm{n}=84$ & $\begin{array}{l}\text { Monoelasztikus szegezés } \\
\text { Endcap rögzítéssel }\end{array}$ & $\mathrm{n}=16$ \\
\hline Bőrirritáció & 9 & Bőrirritáció & 0 \\
\hline Rediszlokáció & 1 & Rediszlokáció & 0 \\
\hline Felületes infekció & 3 & Felületes infekció & 1 \\
\hline Mélyinfekció & 0 & Mélyinfekció & 0 \\
\hline Ín- vagy idegsérülés & 0 & Ín- vagy idegsérülés & 0 \\
\hline
\end{tabular}

\begin{tabular}{|c|c|c|c|c|c|c|c|}
\hline $\begin{array}{l}\text { Kettős elasztikus } \\
\text { szegezés N=84 }\end{array}$ & $\begin{array}{l}1 . \\
\text { hét }\end{array}$ & $\begin{array}{l}4 . \\
\text { hét }\end{array}$ & $\begin{array}{l}24 . \\
\text { hét }\end{array}$ & $\begin{array}{l}\text { Mono-elaszikus szegezés } \\
\text { Endcap rögzítéssel N=16 }\end{array}$ & $\begin{array}{l}1 . \\
\text { hét }\end{array}$ & $\begin{array}{l}4 . \\
\text { hét }\end{array}$ & $\begin{array}{l}24 . \\
\text { hét }\end{array}$ \\
\hline $\begin{array}{l}\text { Kiváló (max. } 5 \text { fok } \\
\text { tengelyeltérés) }\end{array}$ & 70 & 66 & 83 & $\begin{array}{c}\text { Kiváló } \\
\text { (max. } 5 \text { fok tengelyeltérés) }\end{array}$ & 13 & 13 & 16 \\
\hline $\begin{array}{l}\text { Jó (max. } 15 \text { fok } \\
\text { tengelyeltérés) }\end{array}$ & 13 & 17 & 1 & $\begin{array}{c}\text { Jó } \\
\text { (max. } 15 \text { fok tengelyeltérés) }\end{array}$ & 3 & 3 & 0 \\
\hline $\begin{array}{c}\text { Megfelelő } \\
\text { (max. } 30 \text { fok tengelyel- } \\
\text { térés a remodellációs } \\
\text { határon belül) }\end{array}$ & 1 & 0 & 0 & $\begin{array}{c}\text { Megfelelelő } \\
\text { (max. } 30 \text { fok tengelyeltérés } \\
\text { a remodellációs határon } \\
\text { belül) }\end{array}$ & 0 & 0 & 0 \\
\hline $\begin{array}{c}\text { Rossz } \\
\text { (esetleges } \\
\text { remodellációs határon } \\
\text { túli eltérés) }\end{array}$ & 0 & 1 & 0 & $\begin{array}{l}\text { Rossz } \\
\text { (esetleges remodellációs } \\
\text { határon túli eltérés) }\end{array}$ & 0 & 0 & 0 \\
\hline
\end{tabular}




\section{MEGBESZÉLÉS}

A diszlokációval járó gyermekkori distalis radius törések kezeléséről nem találhatóak magas szintű evidenciák az irodalomban (2). Konzervatív kezeléssel többnyire az elmozdulás nélküli, illetve a legalább egyik periosteum intaktságát megtartott törések kezelhetőek problémamentesen $(2,16,22)$. A mútéti eljárást - az elmúlt negyven évben - a tűződrótos osteosynthesis, illetve ennek számos variációja jelentette $(16,22,25)$. Egyes szerzők csak sikertelen konzervatív kezelést követően (első hetekben észlelt remodellációs kapacitást meghaladó rediszlokáció), mások a nagyfokban instabil törések esetén már primeren javasolnak mútétet $(2,16,22)$.

Nem egyértelmű a remodellációs kapacitás határa sem. A 15 fok alatti elmozdulás a fiúknál 12, illetve lányoknál 10 éves kor alatt biztosan elfogadható, az ennél nagyobb, 30-40 fokig terjedő angulációval járó metaphysis törések remodellációs kapacitásáról ugyanakkor megoszlanak a vélemények $(6,9,13)$. A mindkét periosteum átszakadással és megrövidüléssel járó esetekben a rediszlokációs arány még sikeres primer fedett repozíció esetén is 40-50\% lehet $(2,16,22)$.

A gyermekkori distalis diszlokált radiustörések ellátására alkalmazott tűződrótos osteosynthesis nem problémamentes módszer. A szintézis további gipszrögzítést tesz szükségessé, így a gyermek az operatív és konzervatív kezelés hátrányait is elszenvedi. Áttekintve a 2009 és 2014 között az osztályunkon operált eseteinket, meglehetősen magas szövődményarányt észleltünk. Hasonló eredményeket találunk az irodalomban, ahol igen magas, akár 20-40\%-os mútéti szövődményarányokról számolnak be. Ezek nagy része minor szövődmény, bőrirritáció, felületes infekció, de osteomyelitisszel szövődött mélyinfekciókról, iatrogén Galeazzi sérülésről, illetve reosteosynthesist szükségessé tevő rediszlokációkról is találhatóak beszámolók (5, $7,17,20,21$ ). A problémák nagy része ugyan további ellátás keretében kései szövődmények nélkül megoldható (ismételt, illetve prolongált gipszrögzítés, reosteosynthesis stb.), az alkalmazott terápia elhúzódása, a végtag hosszabb immobilizációja, illetve a szükséges kontrollvizsgálatok számának növekedése jelentős időbeli és anyagi terhet jelent, mind a gyermek, mind a család számára. Annak ellenére, hogy nincs egyértelmű bizonyíték arra, hogy a növekedési zónán átvezetett Kirschner-drót növekedési zavart okozna, a legtöbb szerző javasolja azok lehetőség szerinti elkerülését túzés során, illetve a dia-metaphysis átmenetben észlelt törések trans-physealis szintézise után, hosszú távú utánkövetést a physisek állapotának ellenőrzésére $(1,15,18)$.

$A z$ elmúlt években megjelent néhány tanulmány, amelyek során distalis alkartöréseket a physiseket elkerülő elasztikus velőúrszegezés módosított formáival láttak el, de ezek az eljárások is kivétel nélkül igényelnek posztoperatív 4-6 hetes gipszrögzítést $(3,4,10,12)$.

Célunk egy olyan mútéti módszer kidolgozása volt, amely a növekedési zónák megkerülésével, minimál invazív módon, mozgásstabilan biztosítja az elért helyzetet. Az általunk alkalmazott technika a klasszikus ESIN módszer minimális módosításokkal. A biomechanikai elvek lényegében ugyanazok, mint a csöves csontok diaphysis töréseinél alkalmazott hosszú szegek esetében: a csontcorticalis belső rögzítése az elöre meghajlított szeggel úgy, hogy a törés szintje a szeg legnagyobb görbületére essen.

A radius klasszikus elasztikus velőűrszegezése esetén az előre hajlított szeg legnagyobb görbülete a diaphysis magasságában helyezkedik el, így a legnagyobb feszülést a distalisan elhelyezkedő töréstől excentrikusan fejtené ki. A "C"-alakban meghajlított mini szegek esetén a görbület a törés magasságába kerül, így stabilizáló hatását is itt fejti ki.

$A z$ axialis, illetve rotációs stabilitás eléréséhez szükséges a két, különböző pontokról indított, relatív vastag szegek alkalmazása. Gyermekkorban a radius distalis végének a remodellációs kapacitása a növekedési porcok épsége esetén kitűnő. $A$ szintézis során ugyan anatómiai repozícióra törekszünk, de bizonyos fokú tengelyeltérés megengedhető. Az irodalomban általában gyermekkori radius distalis vég törések 15 fok alatti értékét a legtöbb szerző elfogadhatónak tartja. Amennyiben a mútét után ennél nagyobb tengelyeltérés nem alakul ki, a remodelláció általában teljesen végbemegy. Az eseteink egy részénél a közvetlen mútét utáni időszakban készült röntgenfelvételek mérsékelt tengelyeltéréseket igazoltak, ugyanakkor fél évvel később ezek 
mind korrigálódtak. Egy esetben észleltünk nagyobb tengelyeltérést a remodellációs határ közelében, itt reszintézist nem végeztünk, a remodellációs folyamat itt is végbement, de egy évet vett igénybe, a klinikai funkció a harmadik hónaptól ugyanakkor teljes volt.

A szegek bevezetési pontjai (Lister tuberculum és a radius distalis lateralis vége) megfelelnek a radius velőúrszegezésnél használható standard behatolási zónáknak. Bár anyagunkban ín, illetve idegsérülést nem tapasztaltunk, a két bevezetési ponton való áthaladás több szövődmény forrása is lehet (24).

A dorsalis bevezetés a Lister tuberculumon keresztül az extensor pollicis longus ín sérülését, a radialis behatolás a nervus radialis érzőágának laesióját okozhatja. Bár irodalmi adatok és saját, alkar diaphysis törések mütétei során szerzett tapasztalataink alapján is ezeknek a szövődményeknek az esélye alacsony (1-2\% alatti), a kettős szegezési technikával elvileg növelhetjük elöfordulásukat. Az insérülés kiküszöbölésére több megoldás is ismert. A szeg bevezetési pontjának meghatározása történhet intraoperativ szonográfia segítségével, illetve vértelenségben végzett mütét során a Lister-tuberculum feletti kis feltárással direkt láthatóvá tétel mellett (23). A két szeg együttes alkalmazásának további hátránya lehet a bőr irritációja. Anyagunkban ez az esetek 9\%-ában fordult elő, és bár minor szövődménynek tekinthető, a gyermekek komfortérzetét jelentősen rontja.

A fentiek miatt vezettük be a technika egy módosított formáját, amikor a rövid elasztikus szeg végére menetes lágyrészvédőt helyezünk. Az Endcap ${ }^{\circledR}$ zárókupak főleg tibia, illetve femurtörések szegezésénél használatos, az összecsúszás gátlása, a stabilitás fokozása, illetve lágyrészvédelem szempontjából. Alkartáji töréseknél való használata kevésbé terjedt el, egyes szerzők felnőttkori alkartáji törések ESIN technikával való stabilizálása során alkalmazták.

$\mathrm{Az}$ alkar distalis végén való alkalmazásához a korábban említett kis feltárás ennél a technikánál mindenképpen szükséges az inak közelsége és a relatív nagy implantátum méret miatt. Eddigi eseteinknél úgy találtuk, hogy a menetes végú Endcap ${ }^{\circledR}$ stabilitás fokozó hatása a második szeget feleslegessé teszi és a bőr irritációját teljesen megszünteti.

A posztoperatív külső rögzítés során rövid gipszsínt, illetve tépőzáras műanyag brace-t alkalmaztunk. Ez az átmeneti külső rögzítés inkább a kisebb gyermekek esetén volt szükséges, fóleg a komfortérzet javítása céljából, de az esetek 70 százalékában a második hét után teljesen elhagyható volt.

Vizsgálatunknak több gyenge pontja is akad. Egyelöre hiányoznak a prospektív randomizált vizsgálatok, amelyek a fenti technikák előnyeit egyértelmúen igazolnák a hagyományos tűződrótos eljárással, illetve a szintén osztályunkon bevezetett módosított hosszú elasztikus velőűrszegezéssel szemben. Nincsenek biomechanikai adataink az egyszeres Endcap-pal ellátott szeg, illetve kétszeres szegezés stabilitásának erősségéről. (Jelenleg folyamatban van egy biomechanikai vizsgálat, amely az egyes szintézisek stabilitását hasonlítja össze.) A fenti technika valódi szövődmény arányairól csak a tanulási görbe időszakát is figyelembe vevő, jóval nagyobb esetszám elemzése után alkothatunk pontosabb képet.

\section{KÖVETKEZTETÉSEK}

A fenti hiányosságok ellenére úgy gondoljuk, hogy az általunk bevezetésre került rövid szegezési technika jó alternativája lehet $a z$ eddigi standard eljárásnak. Legföbb elönyének a physisek elkerülését, a mozgásstabil szintézis elérését, a csökkent idejü és egyszerüsített külső rögzítést, és a gyermekek gyors rehabilitációját tartjuk. A sikeres mútéti technika az ESIN technikában, illetve gyermektraumatológiában való jártasságot igényel. További tapasztalatainkról nagyobb esetszám, megfelelő összehasonlító klinikai és biomechanikai vizsgálatokat követően fogunk beszámolni. 


\section{IRODALOM}

1. Abzug J. M., Little K., Kozin S. H.: Physeal arrest of the distal radius. J. Am. Acad. Orthop. Surg. 2014. 22: $381-389$. https://doi.org/10.5435/JAAOS-22-06-381

2. Bae D. S., Howard A. W.: Distal radius fractures: what is the evidence? J. Pediatr. Orthop. 2012. 32. Suppl. 2. S128-130. https://doi.org/10.1097/BPO.0b013e31824b2545

3. Cai H., Wang Z., Cai H.: Fixation of distal radial epiphyseal fracture: Comparison of $K$-wire and prebent intramedullary nail. J. Int. Med. Res. 2016. 44. (1): 122-130. https://doi.org/10.1177/0300060514566650

4. Cai H., Wang Z., Cai H.: Prebending of a titanium elastic intramedullary nail in the treatment of distal radius fractures in children. Int. Surg. 2014. 99. (3): 269-275. https://doi.org/10.9738/INTSURG-D-13-00065.1

5. Compagnone L., Ghazal R., Canavese F.: minimally displaced distal radius fracture treated with closed reduction and percutaneous fixation resulting in an iatrogenic Galeazzi lesion. J. Hand Microsurg. 2016. 8. (3): 165-169. https://doi.org/10.1055/s-0036-1597089

6. Do T. T., Strub W. M., Foad S. L., Mehlman C. T., Crawford A. H.: Reduction versus remodeling in pediatric distal forearm fractures: a preliminary cost analysis. J. Pediatr. Orthop. B. 2003. 12. (2): 109-115.

7. Hargreaves D. G., Drew S. J., Eckersley R.: Kirschner wire pin tract infection rates: a randomized controlled trial between percutaneous and buried wires. J. Hand Surg. Br. 2004. 29: 374-376. https://doi.org/10.1016/J.JHSB.2004.03.003

8. Hellebrekers P., de Vries L. S., Timmers T. K.: Displaced distal forearm fractures in children. J. Trauma Treat. 2016. 5. (4): 1000331 https://doi.org/10.4172/2167-1222.1000331

9. Jeroense K. T., America T., Witbreuk M. M., van der Sluijs J. A.: Malunion of distal radius fractures in children. Acta Orthop. 2015. 86. (2): 233-237. https://doi.org/10.3109/17453674.2014.981781

10. Joulié S., Laville J. M., Salmeron F.: Posteromedial elastic stable intramedullary nailing (ESIN) in volarly displaced metaphyso-diaphyseal distal radius fractures in child. Orthop. Traumatol. Surg. Res. 2011. 97. (3): 330-334.

11. Khosla S., Melton L. J., Dekutoski M. B., Achenbach S. J., Oberg A. L., Riggs B. L.: Incidence of childhood distal forearm fractures over 30 years: a population based study. JAMA, 2003. 290. (11): $1479-1485$. https://doi.org/10.1001/iama.290.11.1479

12. Kim B. S., Lee Y. S., Park S. Y., Nho J. H., Lee S. G., Kim Y. H.: Flexible intramedullary nailing of forearm fractures at the distal metadiaphyseal junction in adolescents. Clin. Orthop. Surg. 2017. 9. (1): 101-108. https://doi.org/10.4055/cios.2017.9.1.101

13. Larsen E., Vittas D., Torp-Pedersen S.: Remodeling of angulated distal forearm fractures in children. Clin. Orthop. Relat. Res. 1988. 237: 190-195. https://doi.org/10.1097/00003086-198812000-00027

14. Lee S. C., Han S. H., Rhee S. Y.: Percutaneous transphyseal pin fixation through the distal physis of the ulna in paediatric distal fractures of the forearm. J. Orthop. Trauma, 2013. 27: 462-466. https://doi.org/10.1097/BOT.0b013e3182847174

15. Lieber J., Schmid E., Schmittenbecher P. P.: Unstable diametaphyseal forearm fractures. Transepiphyseal intramedullary Kirschner-wire fixation as a treatment option in children. Eur. J. Pediatr. Surg. 2010. 6: $395-398$. https://doi.org/10.1055/s-0030-1262843

16. McLauchlan G. J., Cowan B., Annan I. H., Robb J. E.: Management of completely displaced metaphyseal fractures of the distal radius in children. A prospective, randomised controlled trial. J. Bone Joint Surg. Br. 2002. 84. (3): $413-417$. https://doi.org/10.1302/0301-620X.84B3.11432

17. Parikh S. N., Jain V. V., Youngquist J.: Intrafocal pinning for distal radius metaphyseal fractures in children. Orthopedics, 2013. 36: 783-788. https://doi.org/10.3928/01477447-20130523-25

18. Pritchett J. W.: Does pinning cause distal radial growth plate arrest? Orthopaedics, 1994. 17: 550.

19. Satish B. R., Vinodkumar M., Suresh M., Seetharam P. Y., Jaikumar K.: Closed reduction and K-wiring with the Kapandji technique for completely displaced pediatric distal radial fractures. Orthopedics, 2014. 37. (9): e810-816. https://doi.org/10.3928/01477447-20140825-58

20. Subramanian P., Kantharuban S., Shilston S., Pearce O. J.: Complications of Kirschner-wire fixation in distal radius fractures. Tech. Hand Up. Extrem. Surg. 2012. 16. (3): 120-123. https://doi.org/10.1097/BTH.0b013e31824b9ab0

21. Tosti R., Foroohar A., Pizzutillo P. D., Herman M. J.: Kirschner wire infections in paediatric orthopaedic surgery. J. Pediatr. Orthop. 2015. 35. (1): 69-73. https://doi.org/10.1097/BPO.0000000000000208

22. Van Leemput W., De Ridder K.: Distal metaphyseal radius fractures in children: reduction with or without pinning. Acta Orthop. Belg. 2009. 75. (3): 306-309.

23. Varga M., Gáti N., Kassai T., Papp S., Pintér S.: Intraoperative sonography may reduce the risk of extensor pollicis longus tendon injury during dorsal entry elastic intramedullary nailing of the radius in children. Medicine (Baltimore), 2018.97. (24): e11167 https://doi.org/10.1097/MD.0000000000011167

24. Varga M., Józsa G., Fadgyas B., Kassai T., Renner A.: Short, double elastic nailing of severely displaced distal pediatric radial fractures: A new method for stable fixation. Medicine (Baltimore), 2017. 96. (14): e6532 https://doi.org/10.1097/MD.0000000000006532

25. Voto S. J., Weiner D. S., Leighley B.: Use of pins and plaster in the treatment of unstable pediatric forearm fractures. J. Pediatr. Orthop. 1990. 10. (1): 85-89. https://doi.org/10.1097/01241398-199001000-00016

\section{Dr. Varga Marcell}

Péterfy Kórház-Rendelőintézet Országos Traumatológiai Intézet

1081 Budapest, Fiumei út 17. 